\title{
Meeting Nationally Determined Contribution Targets: Projecting Kenya's Motor Vehicle Emissions
}

\author{
Fahd Mohamed Omar Al-Guthmy*, Wanglin Yan \\ Graduate School of Media and Governance, Keio University, Tokyo, Japan \\ Email: ^falguthmy@keio.jp
}

How to cite this paper: Al-Guthmy, F.M.O. and Yan, W.L. (2019) Meeting Nationally Determined Contribution Targets: Projecting Kenya's Motor Vehicle Emissions. Low Carbon Economy, 10, 31-46. https://doi.org/10.4236/lce.2019.102003

Received: March 9, 2019

Accepted: June 27, 2019

Published: June 30, 2019

Copyright $\odot 2019$ by author(s) and Scientific Research Publishing Inc. This work is licensed under the Creative Commons Attribution International License (CC BY 4.0).

http://creativecommons.org/licenses/by/4.0/

\section{c) (i) Open Access}

\begin{abstract}
Kenya still uses a purely value-based motor vehicle taxation system. No environmentally focused fiscal policies exist for vehicle ownership and usage, yet up to a quarter of the country's carbon dioxide emissions originate from the transport and energy sectors. To achieve its Nationally Determined Contribution (NDC) objectives for road transport, current vehicle taxes should be revised to reduce emissions through incentivizing newer and hybrid vehicle imports. The study projects Kenya's motor vehicle inventory using business-as-usual scenario building projections to determine the country's emissions and public revenue. The results conclude that vehicle age is directly proportional to the tax rate and therefore motor vehicle $\mathrm{CO}_{2}$ emissions could be decreased significantly by amending the current tax policies to incentivize a shift in consumer car choice and help Kenya meet its NDC emissions reduction target for 2030 .
\end{abstract}

\section{Keywords}

Kenya, $\mathrm{CO}_{2}$ Emissions, Road Transport, Vehicle Tax

\section{Introduction}

Kenya is considered a fiscal state. "A fiscal state is one that uses taxation and similar forms of revenue in order to obtain adequate income for its survival and development... The Kenyan state can currently be considered as being in a period of fiscal expansion" [1]. As one of the fastest growing economies in Africa, the Kenyan government has been faced with a growing need to meet its national budget, and one of the major revenue generators is motor vehicle import taxes which account for up to $12 \%$ of the total annual revenue. 
With a growing population of over 46 million people and a vehicle inventory of about 2.43 million [2], $99 \%$ of which are used when purchased while a negligible number are hybrid vehicles, Kenya has identified its transport system as a high carbon concern. This is partly due to the country growing rapidly without accompanying transportation and infrastructure services. "This lack of policy is made manifest by a transportation system characterized by severe congestion, high-polluting vehicles, lack of pedestrian and bicycle lanes, lack of accessible, high-quality public transport options, and deteriorating infrastructure" [3].

In Kenya's Nationally Determined Contribution (NDC) report tabled at the 2015 United Nations (UN) Climate Change Convention in Paris, it states $25 \%$ of the country's emissions come from the transport and energy sectors, the rest being agricultural outputs. One of the aims of NDC is to achieve a Low carbon and efficient transportation system. To do this, the target pledged is to reduce emissions by $30 \%$ by 2030 relative to the "Business as Usual" (BAU) scenario. However, there seems to be a disconnection between the NDC target and the current taxation system because Kenya has always had a value-based, ad valorem vehicle import tax, revised in 2005. Older cars would be depreciated by $10 \%$ per year and therefore are subject to significantly lower taxes than newer vehicles.

There are two broad classes of vehicle taxes: Direct and differentiated taxes. Direct taxes are charged during the ownership of the vehicle whilst differentiated taxes are those charged in order to own a vehicle. Vehicle import taxes are therefore differentiated taxes and differ from carbon/emissions taxes. Usually, carbon taxes rise with the level of emissions of a given motor vehicle whilst emissions-based differentiated taxes are structured in ways to encourage the purchase of lower-emitting vehicles thereby increasing a country's overall motor vehicle inventory efficiency.

Kenya has had a history of incorporating transport-related policy documents with one of the more recent ones: the 2010 Integrated National Transport Policy sessional paper, highlighting transportation as a major challenge that still needs to be addressed due to inadequate provisions for environmental protection [4].

\section{Key Issues of Vehicle Taxation in Kenya}

Policy solutions are vital. Understanding the behavioral responses of individuals to the actions of government will always be of interest to a wide spectrum of society [5]. It will inform policy-makers to be confident that the policies they pursue will bring about the desired technological changes at acceptable costs [6] reaffirming that car owner's import decisions are heavily influenced by the fiscal policies, therefore meaning that a shift to newer and hybrid imports is highly likely following the implementation of an effective tax model targeting emissions reduction.

Research on a country's NDC feasibility is limited. The gap lies where vehicle fiscal policies alone can influence a country's vehicle inventory to meet emissions targets. A study conducted in 2004 aimed at predicting impacts associated with 
different policies in the automobile industry. The findings observed that increased regulation penalties can result in cost savings for all parties (consumers, producers of vehicles and the government). Therefore, a regulatory standard needs to be applied in order to control the behavior of the consumers concerned [7].

In 2015, the Kenyan government introduced a law that made the excise duty component a flat percentage rate only for vehicles less than 3 years old. According to the 2015-2016 budget statement, this was done in a bid to raise revenue for the Kes. 2.1 trillion budget and to "promote environmentally friendly imports". The law was considered to be a failure because it taxed more expensive and polluting vehicles considerably less than their counterparts. It was reversed in June 2016 back to the previously used value-based, ad valorem tax tariff, having no emissions reductions incentives. To this date, Kenya still uses a purely value-based vehicle import taxation system. No environmentally based fiscal policies exist for passenger vehicle imports and usage, yet up to a quarter of the county's emissions originate from vehicle and energy use.

During the short period when the excise tax was flattened, Kenyan media released some reports about some Kenyans who had identified a legal loophole in order to circumvent the vehicle taxes by bringing cars through neighboring Uganda, which shares a custom territory with Kenya. This observation showed the laws of unintended consequences unfold before the government reversed the tax. Harrington and McConnell in their paper Motor Vehicles and the Environment, state that "vehicle taxes are probably too low and often of the wrong form to reflect the full economic costs to society of vehicle use... There has been strong reluctance... to use prices to reflect external costs". They go on to add, "We observe one of the greatest dilemmas for policymakers-contending with the unintended consequences that often result if the policy is targeted too narrowly on only one issue" [8].

A closer look at the tax structure and trends of vehicle imports in Kenya reveals that older vehicles of up to 8 years are the preferred imports possibly due to their being the lowest taxed. The effects are that "there are too many old vehicles imported into the country which contribute immensely to the high levels of pollutants than the maximum recommended level by the World Health Organization" [9]. The unevenness in age of imported vehicles strongly suggests that taxes have a role to play because vehicles across high and low-price ranges are imported as the oldest allowable imports.

However, a landmark journal that investigated air pollution regulations in 18 countries discouraged the use of declining taxes based on vehicle age. At the time, it concluded, "high taxes on ownership of new vehicles, with declining tax rates as the vehicle ages, also tend to increase the value of older vehicles and reduce their scrappage rate. From an emissions perspective, flat or even increasing taxes on vehicle ownership as a function of age would be preferable to a declining tax rate. Even better would be a tax based on vehicle emissions levels" [10].

Import vehicle taxes can also be used as control mechanisms on a country's vehicle inventory [11]. Therefore, a recurring environmental (emissions-based) 
tax system would be necessary in addition to a new import tax model, primarily to cover the tax revenue shortfall. The Kenyan Government clearly needed to rethink its approach when developing the motor vehicle tax model. Failures such as the recent excise tax bill accounted for several devastating consequences including:

1) Inequity of the excise tax to importers of lower-priced vehicles because the more expensive luxury cars were taxed less, and lower valued vehicle owners ended up paying higher taxes relative to the previous tariff. Also, some importers sought alternatives by leveraging on neighboring country's friendlier laws.

2) This resulted in reduced imports leading to a ripple effect on complementary industries.

3) The revenue authority missing its half-year budget from vehicle taxes by a whopping $20 \%$.

This conundrum poses the obvious question: How will the country be able to achieve its objectives by 2030 for reducing emissions in the transport sector without enormous expenditures in infrastructure or administrative costs and subsequently risking losing its revenues? In order to answer this question, we must look at the key players involved through the triple bottom perspective. The three primary stakeholders that are affected by an emissions-based fiscal policy are connected as follows:

a) The government creates fiscal policies through taxes to earn revenue for the country's development.

b) The ownership or import tax model affects people's car choice criteria such as the age and types of vehicles imported.

c) This in turn influences climate change advocates/lobbyists interests of the overall levels of emissions going forward, which in this case is a $30 \%$ reduction relative to the BAU scenario.

Therefore, this study highlights the current trend of emissions and proposes a shift in fiscal policy which will spur an increase in newer and hybrid vehicle purchases.

Environment-oriented fiscal reforms have been shown to be successful in many countries. "Countries such as Germany, Spain, Sweden, UK, Canada, Austria, Finland, Portugal, USA, South Africa have applied various types of vehiclerelated taxation schemes to control the emissions of greenhouse gases" [12].

We implemented our approach by projecting the country's emissions, taking into consideration Kenya's NDC pledge to reduce emissions by $30 \%$ by 2030 . The contributions of this paper are as follows:

1) We identify various issues with both the current and previous tax regimes including:

a) The failure of both tax tariffs to incorporate an effective environmentally focused fiscal line item;

b) The reversal of the revised tax regime to the old regime due to a lack of consumer equity as narrated by the cabinet secretary at the time;

c) The lack of a contingency to recoup potential deficit in public revenue as a 
result of a new tax;

d) Ineffective incentive to influence consumers to purchase newer and lower-emitting vehicles;

e) Circumvention of taxes by some vehicle importers using a legal loophole that allows vehicles registered in neighboring countries to be used within the country.

2) We project motor vehicle emissions to 2030 to addresses the issues identified by the motor vehicle tax regimes that have been used in order to justify a newer and lower-emitting national vehicle inventory through a policy shift.

Reference [13] focused on vehicle taxes to investigate its impacts on adoption of lower emitting passenger cars in local Japanese cities. $60 \%$ of the vehicles were reported as low-emitting vehicles. They concluded that a combination of incentives would've been necessary for such a surge and adoption. In a 2006 paper, [14] mentions market disadvantage and lack of cost-effectiveness in adoption of low emitting and alternative fuel vehicles by consumers. As implied, cost-effectiveness means such vehicles cannot compete price-wise with their conventional counterparts, which seems to be the situation in Kenya. Market disadvantage means government intervention and exemptions are required to enhance favorability of these vehicles [14].

\section{Methods and Analysis}

In order to project Kenya's emissions and revenues from light-duty road transport to 2030, scenario building was used to evaluate the practicality of the model. Scenario building is a method of determining future possibilities of a given case study based on the analysis of the present and historical trends. The simulation's aim was to establish vehicle inventory distribution and use that dataset to project emissions and revenues by 2030. Actual vehicle data is used to determine the emissions and tax values as follows using 2018 as the base year. Secondary data was also used from several sources to project scenarios of emissions and revenues to 2030. Methods of projection used included interpolation and linear trend analysis.

For the BAU scenario, using the data sources indicated, it was possible to have baseline statistics and use the trend to project the 2030 emissions, vehicle inventory and revenues. Each scenario uses historical data from several sources including:

1) Historical vehicle distribution, efficiency, emissions and other statistics from the GFEI study conducted in conjunction with the UNEP [15];

2) A University of Nairobi Enterprises and Services Ltd Final draft report of a fuel economy labeling and feebate program for cars in Kenya [12];

3) Historical vehicle inventory Statistics from 2013 [16] to 2016 Kenya National Bureau of Statistics Economic Surveys [17];

4) Hybrid vehicles fuel efficiency and emissions data from the UK-Vehicle Certifications Agency website, accessed on April 1st, 2018. 


\subsection{Business as Usual (BAU) Scenario (2018-2030)}

The basis of this scenario is to act as a baseline using historical data of car import trends from 2010 to 2015 and projecting the vehicle import trajectory onwards to the year 2030 in an increment of 3 years to 2018 and subsequently in increments of 5 years.

According to [15], the following facts were provided:

1) Vehicles over the assessed period (2010-2012) had an average fuel economy of $7.5 \mathrm{~L} / 100 \mathrm{Km}$ and $181.7 \mathrm{gCO}_{2} / \mathrm{Km}$. The average fuel economy for new vehicles was $15.5 \mathrm{~km} / \mathrm{l}$ and $13.6 \mathrm{~km} / \mathrm{l}$ for used vehicles.

2) Hybrid imports in that period totaled a mere 88 units. The fuel economy indicated was about $4 \mathrm{~L} / 100 \mathrm{Km}$ attributed to the Toyota Prius.

3) $1 \%$ of registered Light-Duty vehicles (LDVs) were new while $99 \%$ were used vehicles.

4) $86 \%$ of registered LDVs were petrol powered while $14 \%$ were diesel powered.

5) Vehicles were concentrated in the 8-year age bracket.

6) The preferred engine displacements (size) were in the ranges of 1301-1500 cc and 1501-2000 cc, which together constitute 72\% of Light-Duty Vehicles.

The vehicle inventory used in this study consisted of all light-duty motor vehicles excluding motor-cycles and the data arranged as in Table 1. Vehicle distribution percentages show the number of vehicles within each engine size band according to [15]. Engine size bands were used because [15], in addition to [12], state that both tax and emissions would incrementally and consistently increase with engine size.

In addition, the vehicles were further subdivided into 3 categories, namely new, used and hybrid vehicles. The new and used vehicles contained both gasoline and diesel vehicles whilst the hybrid segment consisted of petrol vehicles alone.

Table 2 shows the cumulative totals of all vehicles after adding the newly registered vehicles into the existing fleet. Actual data runs from 2010 to 2015 and projected onwards using a line of best fit. All projected years are marked by an asterisk.

\subsubsection{Calculating the Emissions Levels}

Several key variables needed to be calculated or obtained in order to be able to effectively project the emissions under the business as usual scenario. First, the average combined test cycle fuel efficiency of new and used vehicles was obtained from the GFEI study. The difference between the two efficiencies (15.15 $\mathrm{km} / \mathrm{l}$ and $13.16 \mathrm{~km} / \mathrm{l}$ ) was used to calculate the efficiency loss between new and 8-year-old cars. Table 3 illustrates this.

Secondly, both the emission rates in grams of $\mathrm{CO}_{2}$ eq per $\mathrm{km}$ driven for each segment (new, used and hybrid vehicles) and engine size bands were necessary. Emission rates for each engine size band were obtained from Kenduiwo's study. Table 4 illustrates the resultant emission rates based on the age of the vehicle and the engine size bands. 
Table 1. Estimated newly registered vehicle distribution in Kenya.

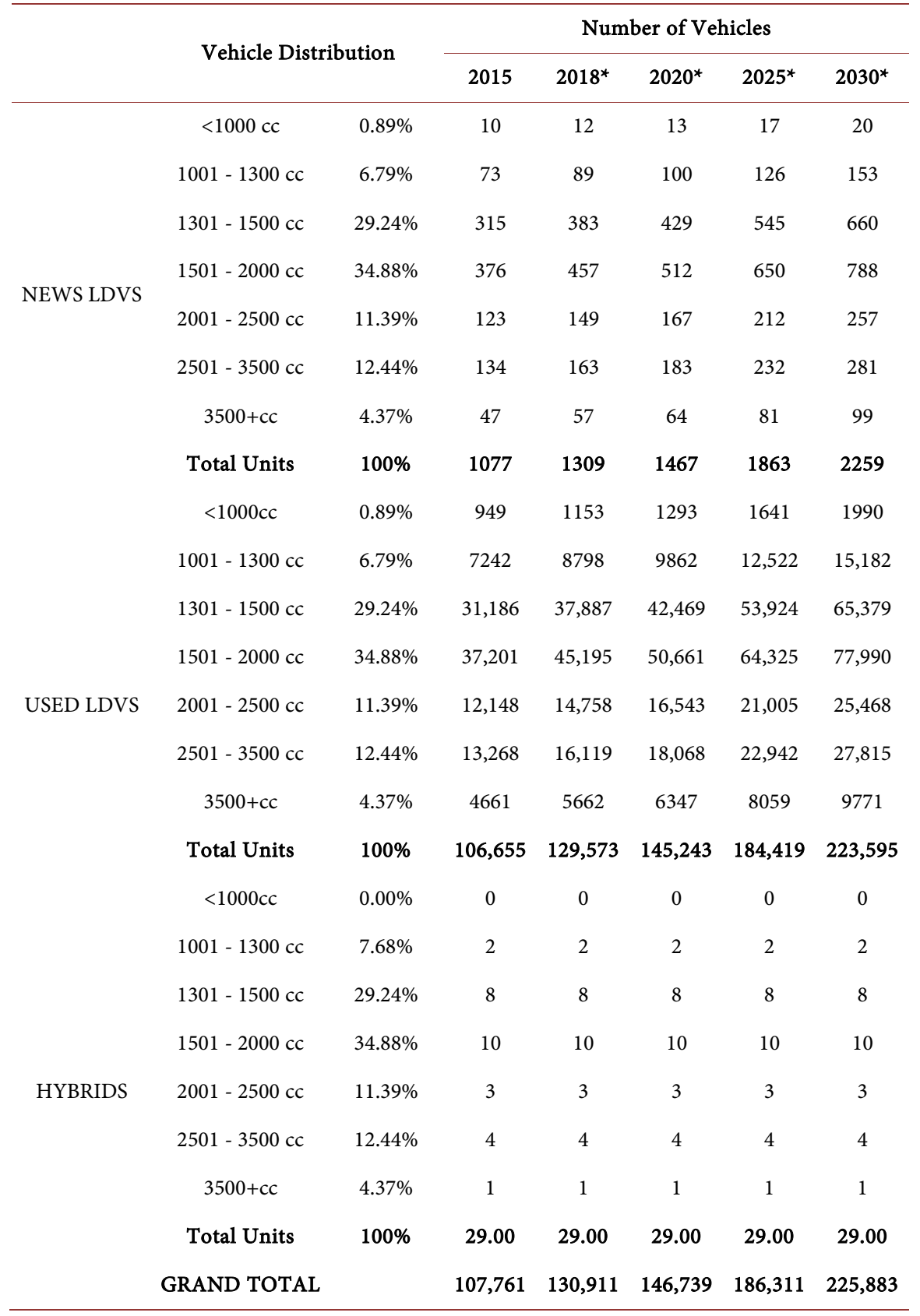

Table 2. Total projected vehicle inventory in Kenya.

\begin{tabular}{ccccc}
\hline Year & $\mathbf{2 0 1 0}$ & $\mathbf{2 0 1 5}$ & $\mathbf{2 0 1 8}^{*}$ & $\mathbf{2 0 3 0}^{*}$ \\
\hline Used Vehicles & 78,359 & 106,655 & 129,573 & 223,595 \\
New Vehicles & 792 & 1077 & 1309 & 2259 \\
Hybrid Vehicles & 40 & 29 & 29 & 29 \\
Total Vehicles & 79,190 & 107,761 & 130,911 & 225,883 \\
Cumulative Total & $1,367,707$ & $2,434,008$ & $2,999,764$ & $5,432,064$ \\
\hline
\end{tabular}

Data source: (Kenya National Bureau of Statistics, 2016). 
Table 3. Distribution of vehicles based on efficiency.

\begin{tabular}{cccccccccc}
\hline Age of Car & $0-1$ & 2 & 3 & 4 & 5 & 6 & 7 & 8 \\
\hline Average Fuel Efficiency $(\mathrm{km} / \mathrm{l})$ & 15.15 & 14.87 & 14.58 & 14.30 & 14.01 & 13.73 & 13.44 & 13.16 \\
Percentage Efficiency & $100.00 \%$ & $98.12 \%$ & $96.24 \%$ & $94.36 \%$ & $92.48 \%$ & $90.60 \%$ & $88.72 \%$ & $86.84 \%$ \\
\hline
\end{tabular}

Table 4. Emissions tabulation.

\begin{tabular}{|c|c|c|c|c|c|c|c|c|c|c|}
\hline \multirow{3}{*}{ Engine Size } & Vehicle Age (Y) & 8 & 7 & 6 & 5 & 4 & 3 & 2 & $0-1$ & \multirow{3}{*}{$\begin{array}{c}\text { Average } \\
\text { Emissions } \\
\left(\mathrm{gCO}_{2} \text { eq } / \mathrm{KM}\right.\end{array}$} \\
\hline & Efficiency Loss & $13.16 \%$ & $11.28 \%$ & $9.40 \%$ & $7.52 \%$ & $5.64 \%$ & $3.76 \%$ & $1.88 \%$ & $0.00 \%$ & \\
\hline & $\begin{array}{l}\text { Average Emissions } \\
\mathrm{gCO}_{2} \mathrm{eq} / \mathrm{km}\end{array}$ & \multicolumn{8}{|c|}{$\mathrm{gCO}_{2} \mathrm{eq} / \mathrm{km}$} & \\
\hline$<1000 \mathrm{cc}$ & 113.94 & 128.93 & 126.79 & 124.65 & 122.51 & 120.37 & 118.22 & 116.08 & 113.94 & 127.99 \\
\hline $1001-1,300 \mathrm{cc}$ & 148.63 & 168.19 & 165.39 & 162.60 & 159.81 & 157.01 & 154.22 & 151.42 & 148.63 & 166.96 \\
\hline $1301-1500 \mathrm{cc}$ & 146.86 & 166.18 & 163.42 & 160.66 & 157.90 & 155.14 & 152.38 & 149.62 & 146.86 & 164.97 \\
\hline $1501-2,000 \mathrm{cc}$ & 167.35 & 189.37 & 186.22 & 183.08 & 179.93 & 176.79 & 173.64 & 170.50 & 167.35 & 187.99 \\
\hline $2001-2500 c c$ & 194.27 & 219.83 & 216.18 & 212.53 & 208.88 & 205.23 & 201.57 & 197.92 & 194.27 & 218.23 \\
\hline $2501-3500 c c$ & 214.66 & 242.90 & 238.87 & 234.83 & 230.80 & 226.76 & 222.73 & 218.69 & 214.66 & 241.13 \\
\hline $3500+c c$ & 279.08 & 315.80 & 310.56 & 305.31 & 300.06 & 294.82 & 289.57 & 284.33 & 279.08 & 313.50 \\
\hline Averages & 180.68 & 204.46 & 201.06 & 197.67 & 194.27 & 190.87 & 187.48 & 184.08 & 180.68 & \\
\hline
\end{tabular}

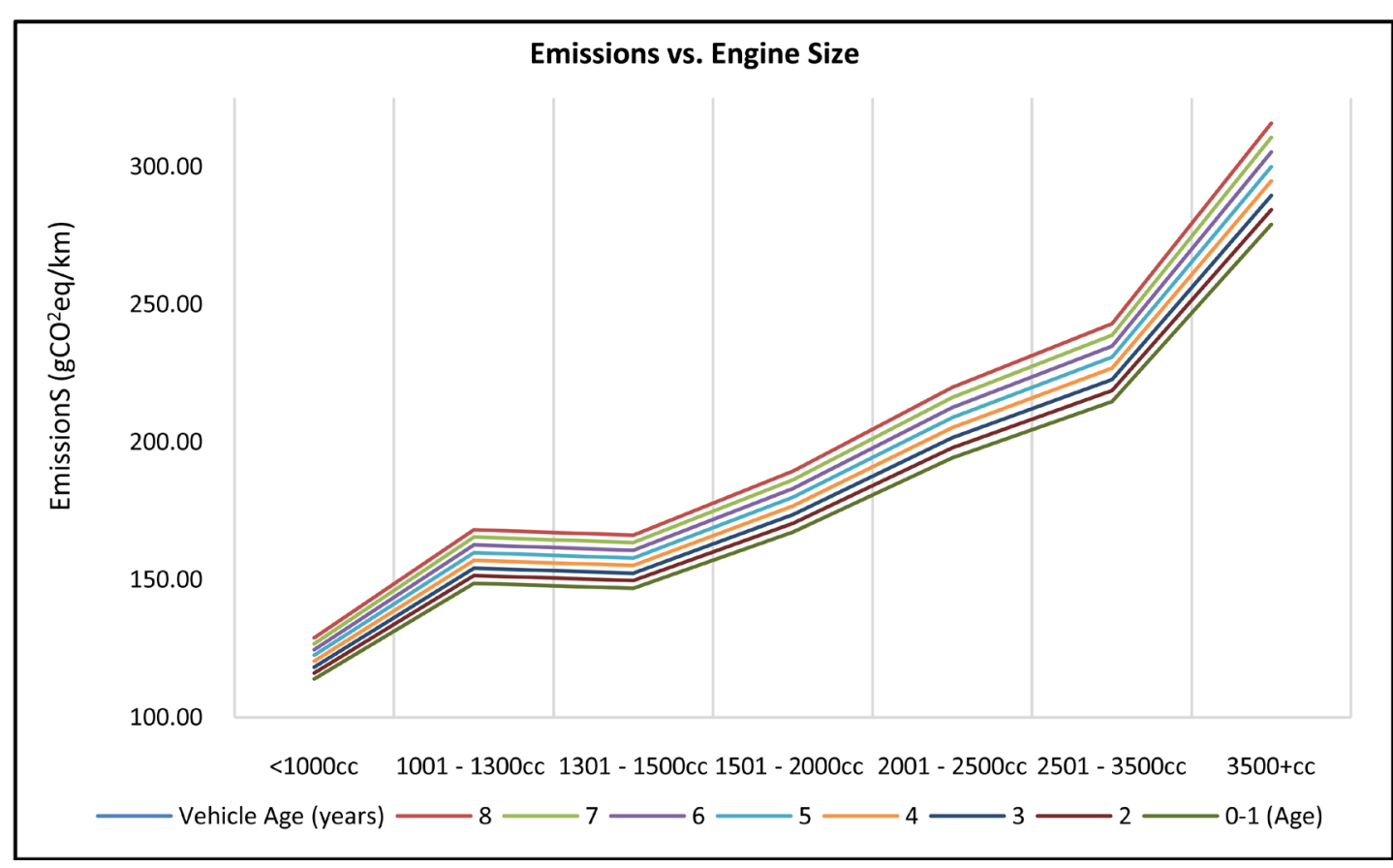

Figure 1. Emissions increase proportionally with engine rating using tabulated data.

For hybrid vehicles (Figure 1), the only emission rate obtained from [15] was for the Toyota Prius (1497 cc) which was used for the 1301 - $1500 \mathrm{cc}$ band. Due to the difficulty in obtaining reliable average fuel economies and/or emission rates for the other hybrid vehicle engine size bands in Kenya, we used sample 
vehicles' figures obtained from the internet [18] for the purposes of this study. The vehicles used are shown in Table 5.

Finally, the total emissions were calculated by multiplying the emission rates by the volume of vehicles per engine size band and adding them to give a final indicative projection of the emission rates up to the year 2030 under the BAU scenario as shown in Table 6.

Table 5. Hybrid vehicle emission samples used.

\begin{tabular}{cccc}
\hline Engine Size & Vehicle sample & $\begin{array}{c}\text { Average Fuel } \\
\text { Economy } 1 / 100 \mathrm{~km}\end{array}$ & $\begin{array}{c}\text { Average Emissions } \\
\mathrm{Gco}_{2} \text { eq/Km }\end{array}$ \\
\hline$<1000 \mathrm{cc}$ & Suzuki Wagon Stingray $(658 \mathrm{cc})$ & 3.47 & 80.50 \\
$1001-1300 \mathrm{cc}$ & Honda Insight $(1330 \mathrm{cc})$ & 4.14 & 96.00 \\
$1301-1500 \mathrm{cc}$ & Toyota Prius $(1497 \mathrm{cc})$ & 3.97 & 92.00 \\
$1501-2000 \mathrm{cc}$ & Toyota Auris $(1798 \mathrm{cc})$ & 3.41 & 79.00 \\
$2001-2500 \mathrm{cc}$ & Harrier Hybrid $(2493 \mathrm{cc})$ & 4.57 & 106.00 \\
$2501-3500 \mathrm{cc}$ & Lexus GS450h 2010 $(3456 \mathrm{cc})$ & 8.02 & 186.00 \\
$3500+\mathrm{cc}$ & Lexus LS600h $(4969 \mathrm{cc})$ & 8.58 & 199.00 \\
\hline
\end{tabular}

Data source: Vehicle Certification Agency Website [18].

Table 6. Estimated emissions output in each category.

\begin{tabular}{|c|c|c|c|c|c|c|c|c|}
\hline & \multirow{2}{*}{ Vehicle Distribution } & \multirow{2}{*}{$\begin{array}{c}\text { Average Fuel } \\
\text { Economy } \\
\text { L/100 KM }\end{array}$} & \multirow{2}{*}{$\begin{array}{l}\text { Total Emissions } \\
\mathrm{gCO}_{2} \mathrm{eq} / \mathrm{km}\end{array}$} & \multicolumn{5}{|c|}{ Number of Vehicles } \\
\hline & & & & 2015 & 2018 & 2020 & 2025 & 2030 \\
\hline \multirow{8}{*}{ NEW } & $<1000 \mathrm{cc}$ & 6.34 & 113.94 & 10 & 12 & 13 & 17 & 20 \\
\hline & $1001-1,300 \mathrm{cc}$ & 6.55 & 148.63 & 73 & 89 & 100 & 126 & 153 \\
\hline & $1301-1500 c c$ & 6.47 & 146.86 & 315 & 383 & 429 & 545 & 660 \\
\hline & $1501-2,000 c c$ & 7.18 & 167.35 & 376 & 457 & 512 & 650 & 788 \\
\hline & $2001-2500 c c$ & 7.78 & 194.27 & 123 & 149 & 167 & 212 & 257 \\
\hline & $2501-3500 c c$ & 8.39 & 214.66 & 134 & 163 & 183 & 232 & 281 \\
\hline & $3500+c c$ & 12.10 & 279.08 & 47 & 57 & 64 & 81 & 99 \\
\hline & Total Units & & & 1077 & 1309 & 1467 & 1863 & 2259 \\
\hline \multirow{10}{*}{ USED } & Total Emissions $\left(\mathrm{KgCO}_{2}\right.$ eq $\left./ \mathrm{km}\right)$ & & & 145.62 & 176.81 & 198.13 & 251.44 & 304.75 \\
\hline & $<1000 \mathrm{cc}$ & 7.12 & 127.99 & 949 & 1153 & 1293 & 1641 & 1990 \\
\hline & $1001-1,300 \mathrm{cc}$ & 7.36 & 166.96 & 7242 & 8798 & 9862 & 12,522 & 15,182 \\
\hline & $1301-1500 c c$ & 7.27 & 164.97 & 31,186 & 37,887 & 42,469 & 53,924 & 65,379 \\
\hline & $1501-2,000 c c$ & 8.07 & 187.99 & 37,201 & 45,195 & 50,661 & 64,325 & 77,990 \\
\hline & $2001-2500 c c$ & 8.74 & 218.23 & 12,148 & 14,758 & 16,543 & 21,005 & 25,468 \\
\hline & $2501-3500 c c$ & 9.42 & 241.13 & 13,268 & 16,119 & 18,068 & 22,942 & 27,815 \\
\hline & $3500+c c$ & 13.59 & 313.50 & 4661 & 5662 & 6347 & 8059 & 9771 \\
\hline & Total Units & & & 106,655 & 129,573 & 145,243 & 184,419 & 223,595 \\
\hline & Total Emissions $\left(\mathrm{KgCO}_{2} \mathrm{eq} / \mathrm{km}\right)$ & & & 16,138 & 19,605 & 21,977 & 27,904 & 33,832 \\
\hline
\end{tabular}




\section{Continued}

\begin{tabular}{|c|c|c|c|c|c|c|c|c|}
\hline & $<1000 \mathrm{cc}$ & 3.47 & 80.50 & 0 & 0 & 0 & 0 & 0 \\
\hline & $1001-1300 \mathrm{cc}$ & 4.14 & 96.00 & 2 & 2 & 2 & 2 & 2 \\
\hline & $1301-1500 \mathrm{cc}$ & 3.97 & 92.00 & 8 & 8 & 8 & 8 & 8 \\
\hline & $1501-2000 c c$ & 3.41 & 79.00 & 10 & 10 & 10 & 10 & 10 \\
\hline \multirow[t]{7}{*}{ HYBRID } & $2001-2500 \mathrm{cc}$ & 4.57 & 106.00 & 3 & 3 & 3 & 3 & 3 \\
\hline & $2501-3500 \mathrm{cc}$ & 8.02 & 186.00 & 4 & 4 & 4 & 4 & 4 \\
\hline & $3500+c c$ & 8.58 & 199.00 & 1 & 1 & 1 & 1 & 1 \\
\hline & Total Units & & & 29.00 & 29.00 & 29.00 & 29.00 & 29.00 \\
\hline & Total Emissions $\left(\mathrm{KgCO}_{2} \mathrm{eq} / \mathrm{km}\right)$ & & & 2.53 & 2.53 & 2.53 & 2.53 & 2.53 \\
\hline & OVERALL UNITS & & & 107,761 & 130,911 & 146,739 & 186,311 & 225,883 \\
\hline & OVERALL EMISSIONS $\left(\mathrm{tCO}_{2} \mathrm{eq} / \mathrm{km}\right)$ & & & 16.286 & 19.785 & 22.178 & 28.159 & 34.140 \\
\hline
\end{tabular}

Table 7. Distribution of vehicles by age.

\begin{tabular}{cccccccccc}
\hline AGE & 8 & 7 & 6 & 5 & 4 & 3 & 2 & $0-1$ & Total \\
\hline NUMBER OF VEHICLES & 61,492 & 18,580 & 2,290 & 444 & 434 & 180 & 808 & 762 & 84,990 \\
PERCENT & $72.35 \%$ & $21.86 \%$ & $2.69 \%$ & $0.52 \%$ & $0.51 \%$ & $0.21 \%$ & $0.95 \%$ & $0.90 \%$ & $100 \%$ \\
\hline
\end{tabular}

\subsubsection{Calculating the Revenues Generated}

The age of the vehicles imported into Kenya for each year was obtained by using the vehicle age table in [15] which showed that $67 \%$ of the vehicles for the year 2012 consisted of 8 years old vehicles, $20 \%$ for 7 -year-old vehicles and $0.9 \%$ for years 0 - 1. It was then possible to allocate the range of vehicle proportions for the remaining years and converting the differences into percentages as shown in Table 7 for use in the tax tabulation.

In order to calculate the tax due for each vehicle category (i.e. engine size band and age of vehicle), each engine size band was allocated a weight based on the 2011 tax revenues from [12] ranging from 4 to 42, the highest being the largest engine size vehicles. Therefore, the method assumed that the bigger the engine, the higher the assumed tax payable based on historical tax revenue. Since the tax rate for the BAU method is determined by the age of the vehicle as well, the total tax payable per year of manufacture was calculated using the vehicle import tax formula as shown in Equation (1):

$$
\begin{aligned}
T T= & 25 \%(D P \times M V)+20 \%(25 \%(D P \times M V)+M V) \\
& +16 \%(25 \%(D P \times M V)+20 \%(25 \%(D P \times M V)+M V))
\end{aligned}
$$

where:

$\begin{array}{lll}\text { Abbreviation } & \text { Term } & \text { Expression } \\ D P & \text { Depreciation Rate } & \mathrm{X} \% \\ C T & \text { Customs Tax } & (\mathrm{DP} \times \mathrm{MV}) \times 25 \% \\ X T & \text { Excise Tax } & 20 \%(\mathrm{MV}+\mathrm{TC}) \\ V T & \text { Value Added Tax } & 16 \%(\mathrm{MV}+\mathrm{TC}+\mathrm{TX}) \\ T T & \text { Total Tax } & \mathrm{TC}+\mathrm{TX}+\mathrm{TV}\end{array}$


Therefore, the formula can be simply stated as shown in Equation (2):

$$
T T=T C+T X+T V
$$

The depreciation of vehicles was also made according to the predefined Kenya Revenue Authority Motor Vehicle depreciation rate of $10 \%$ per annum. With all the required data, it was then possible to calculate the weighted tax under the BAU scenario using Equation (3):

$$
T A X C O=W \times D \times(100 \%+T R) \times Y O M V
$$

where:

TAXCO is the Tax coefficient;

$W$ is the weight;

$D$ is Depreciation;

$T R$ is the taxation rate;

$Y O M V$ is the Year of manufacture volume.

Table 8 highlights the tax bands for all vehicle ages and all engine sizes.

The tax coefficient was then embedded into the projection table and multiplied by the volume of vehicles in each year projected. The resulting figures are shown in Table 9.

\subsection{Overall Results}

The results of the BAU scenario projection indicate that in the year 2030, ceteris paribus, there will be $34.14 \mathrm{tCO}_{2} \mathrm{eq} / \mathrm{km}$ from the imports of that year alone relative to $19.79 \mathrm{tCO}_{2} \mathrm{eq} / \mathrm{km}$ in 2018. Cumulative figures were processed through interpolation techniques to achieve the final output.

Table 10 shows that by 2030, the emissions from additional vehicles registered

\begin{tabular}{|c|c|c|c|c|c|c|c|c|c|c|}
\hline & Vehicle Age (Y) & 7 & 6 & 5 & 4 & 3 & 2 & 1 & 0 & \\
\hline & Depreciation Value & 0.3 & 0.4 & 0.5 & 0.6 & 0.7 & 0.8 & 0.9 & 1 & Vehicle \\
\hline & Tax Rate & $10.21 \%$ & $13.61 \%$ & $17.01 \%$ & $20.41 \%$ & $23.82 \%$ & $27.22 \%$ & $30.62 \%$ & $32.32 \%$ & $\begin{array}{l}\text { Revenue } \\
\text { Coefficient }\end{array}$ \\
\hline & YOMV & $72.35 \%$ & $21.86 \%$ & $2.69 \%$ & $0.52 \%$ & $0.51 \%$ & $0.21 \%$ & $0.95 \%$ & $0.90 \%$ & per Engine Size \\
\hline Engine Size & Weight (X) & & & & & & & & & \\
\hline$<1000 \mathrm{cc}$ & 4.565697123 & 3.6405 & 1.1340 & 0.1439 & 0.0287 & 0.0289 & 0.0123 & 0.0567 & 0.0542 & 5.05 \\
\hline $1001-1300 \mathrm{cc}$ & 5.669079826 & 4.5204 & 1.4080 & 0.1787 & 0.0357 & 0.0358 & 0.0153 & 0.0704 & 0.0673 & 6.26 \\
\hline $1301-1500 \mathrm{cc}$ & 6.28821978 & 5.0140 & 1.5618 & 0.1983 & 0.0396 & 0.0398 & 0.0169 & 0.0781 & 0.0746 & 6.95 \\
\hline $1501-2000 \mathrm{cc}$ & 9.311203262 & 7.4245 & 2.3126 & 0.2936 & 0.0586 & 0.0589 & 0.0251 & 0.1156 & 0.1105 & 10.29 \\
\hline $2001-2500 \mathrm{cc}$ & 14.20733889 & 11.3285 & 3.5286 & 0.4479 & 0.0894 & 0.0898 & 0.0383 & 0.1764 & 0.1685 & 15.70 \\
\hline $2501-3500 \mathrm{cc}$ & 17.51326071 & 13.9645 & 4.3497 & 0.5522 & 0.1102 & 0.1107 & 0.0472 & 0.2175 & 0.2078 & 19.35 \\
\hline $3500+c c$ & 42.44520041 & 33.8445 & 10.5419 & 1.3382 & 0.2670 & 0.2684 & 0.1144 & 0.5271 & 0.5035 & 46.90 \\
\hline $\begin{array}{c}\text { Total Revenue Coefficient } \\
\text { Per Vehicle Age }\end{array}$ & & 79.74 & 24.84 & 3.15 & 0.63 & 0.63 & 0.27 & 1.24 & 1.19 & 111.69 \\
\hline
\end{tabular}

Table 8. Breakdown of tax bands for the BAU projection. 
Table 9. Tax distribution results.

\begin{tabular}{|c|c|c|c|c|c|c|c|c|}
\hline \multirow{2}{*}{\multicolumn{2}{|c|}{ Vehicle Distribution }} & & \multirow{2}{*}{ Tax Coefficient } & \multicolumn{5}{|c|}{ Number of Vehicles } \\
\hline & & & & 2015 & 2018 & 2020 & 2025 & 2030 \\
\hline \multirow{8}{*}{ NEWS LDVS } & $<1000 c c$ & $0.89 \%$ & 0.054165122838 & 10 & 12 & 13 & 17 & 20 \\
\hline & $1001-1300 c c$ & $6.79 \%$ & 0.067255097493 & 73 & 89 & 100 & 126 & 153 \\
\hline & $1301-1500 \mathrm{cc}$ & $29.24 \%$ & 0.074600260950 & 315 & 383 & 429 & 545 & 660 \\
\hline & $1501-2000 \mathrm{cc}$ & $34.88 \%$ & 0.110463408960 & 376 & 457 & 512 & 650 & 788 \\
\hline & $2001-2500 \mathrm{cc}$ & $11.39 \%$ & 0.168548687133 & 123 & 149 & 167 & 212 & 257 \\
\hline & $2501-3500 \mathrm{cc}$ & $12.44 \%$ & 0.207768472647 & 134 & 163 & 183 & 232 & 281 \\
\hline & $3500+c c$ & $4.37 \%$ & 0.503548402856 & 47 & 57 & 64 & 81 & 99 \\
\hline & Total Units & $100 \%$ & 1.19 & 1077 & 1309 & 1467 & 1863 & 2259 \\
\hline \multirow{9}{*}{ USED LDVS } & Total Tax KES ('000) & & & 142.68 & 173.34 & 194.30 & 246.71 & 299.12 \\
\hline & $<1000 \mathrm{cc}$ & $0.89 \%$ & 5.045043857706 & 949 & 1153 & 1293 & 1641 & 1990 \\
\hline & $1001-1300 \mathrm{cc}$ & $6.79 \%$ & 6.264269307119 & 7242 & 8798 & 9862 & 12,522 & 15,182 \\
\hline & $1301-1500 c c$ & $29.24 \%$ & 6.948411977514 & 31,186 & 37,887 & 42,469 & 53,924 & 65,379 \\
\hline & $1501-2000 c c$ & $34.88 \%$ & 10.288774652023 & 37,201 & 45,195 & 50,661 & 64,325 & 77,990 \\
\hline & $2001-2500 \mathrm{cc}$ & $11.39 \%$ & 15.698949327448 & 12,148 & 14,758 & 16,543 & 21,005 & 25,468 \\
\hline & $2501-3500 \mathrm{cc}$ & $12.44 \%$ & 19.351955683587 & 13,268 & 16,119 & 18,068 & 22,942 & 27,815 \\
\hline & $3500+c c$ & $4.37 \%$ & 46.901468025784 & 4661 & 5662 & 6347 & 8059 & 9771 \\
\hline & Total Units & $100 \%$ & 110.50 & 106,655 & 129,573 & 145,243 & 184,419 & 223,595 \\
\hline \multirow{12}{*}{ HYBRIDS } & Total Tax KES ('000) & & & $1,315,667$ & $1,598,379$ & $1,791,686$ & $2,274,954$ & $2,758,222$ \\
\hline & $<1000 c c$ & $0.00 \%$ & 5.099208980544 & 0 & 0 & 0 & 0 & 0 \\
\hline & $1001-1300 \mathrm{cc}$ & $7.68 \%$ & 6.331524404612 & 2 & 2 & 2 & 2 & 2 \\
\hline & $1301-1500 \mathrm{cc}$ & $29.24 \%$ & 7.023012238464 & 8 & 8 & 8 & 8 & 8 \\
\hline & $1501-2000 c c$ & $34.88 \%$ & 10.399238060983 & 10 & 10 & 10 & 10 & 10 \\
\hline & $2001-2500 \mathrm{cc}$ & $11.39 \%$ & 15.867498014581 & 3 & 3 & 3 & 3 & 3 \\
\hline & $2501-3500 \mathrm{cc}$ & $12.44 \%$ & 19.559724156234 & 4 & 4 & 4 & 4 & 4 \\
\hline & $3500+c c$ & $4.37 \%$ & 47.405016428640 & 1 & 1 & 1 & 1 & 1 \\
\hline & Total Units & $100 \%$ & 111.69 & 29.00 & 29.00 & 29.00 & 29.00 & 29.00 \\
\hline & Total Tax Value & & & 361.90 & 361.90 & 361.90 & 361.90 & 361.90 \\
\hline & OVERALL UNITS & & & 107,761 & 130,911 & 146,739 & 186,311 & 225,883 \\
\hline & OVERALL TAX VALUE KES ('000) & & & $1,316,172$ & $1,598,915$ & $1,792,243$ & $2,275,563$ & $2,758,884$ \\
\hline
\end{tabular}

Table 10. Overall results of projection under the BAU scenario.

\begin{tabular}{|c|c|c|c|}
\hline & 2018 & \multicolumn{2}{|c|}{2030} \\
\hline Number of Vehicles & \multicolumn{2}{|c|}{ BAU } & $+1-$ \\
\hline New & 1309 & 2259 & \\
\hline Used & 129,573 & 223,595 & \\
\hline Hybrid & 29 & 29 & \\
\hline Total & 130,911 & 225,883 & \\
\hline Total Tax Factor & $1,598,915$ & $2,758,884$ & 72550 \\
\hline Total Emissions $\left(\mathrm{tCO}_{2} \mathrm{eq} / \mathrm{km}\right)$ & 19.785 & 34.140 & $12.55 \%$ \\
\hline
\end{tabular}


amount to $34.14 \mathrm{tCO}_{2} \mathrm{eq} / \mathrm{km}$. Both taxes and emissions are expected to grow by $72.55 \%$ between 2018 and 2030 similar to the NDC projection. Hybrid imports however did not increase and remained at negligible levels of 29 units per year. Tax value increased albeit attributed to 7-8-year-old used conventional vehicles.

The Kenya NDC target expects to achieve a 30\% overall reduction by 2030 and this study has shown that road transport needs to be addressed in order to contribute to that reduction target. Emissions could be reduced significantly by incentivizing an increase in the importation of both newer and hybrid vehicles. The reduction on emissions can be further achieved if the study considers the likelihood of reduced vehicle purchases as a result of tax penalties on luxurious, usually more polluting vehicles.

\subsection{Discussions}

Fiscal measures provide a strong incentive value, for example, by encouraging the rapid renewal of imported cars and influencing consumer's behavior towards more fuel-efficient passenger cars [11]. This has been evident with the need to amend the current tax legislation to incentivize new and hybrid vehicle imports in Kenya.

Furthermore, according to the findings of [11], increasing the financial burden on owners of highly polluting motor vehicle ownership through the introduction of an emissions tax opens up the possibility of lowering overall emissions and reducing the deficit in public revenue. Influencing consumer behavior requires a well-established fiscal measure that hinders neither public revenue nor subsequent economic and infrastructure development goals [11].

We have developed a substantial case showing the need to revise the current tax model and to internalize the social costs related to $\mathrm{CO}_{2}$ emissions. This is because it is simple and easy to administer, making it a good candidate for a policy on which other countries may adopt. A journal article regarding tax compliance concluded that they "generally found that increased perceptions of [tax] fairness led to improved compliance" [19]. This could explain why the government perceived the current and previous tax tariffs as unjust.

Even though we are not the first to point this out, the apparent mismatch between the existing policies and this prescription suggests that public authorities have not been very effective in developing the right emissions focused policies in Kenya. We would begin by changing the current tax tariff line items so that they match the externalities they affect.

Our evidence, albeit based on a projection of a baseline scenario, had sufficient statistical indication to show evidence that newer vehicle imports should be increased urgently. Norway reformed its vehicle registration tax to reduce emission levels of new cars by incentivizing the purchase of more fuel-efficient cars. A study by [20] showed that the average $\mathrm{CO}_{2}$ intensity of new vehicles in Norway was reduced in the year of the implementation of the tax reform by $12 \%$.

"The observed reduction is due to a combination of improvements in fuel effi- 
ciency of the vehicles available on the market and a shift in the demand side, which could be a reaction to 2007 reform of the registration tax." [20]. This indicates that tax reforms can indeed be highly effective in influencing the types of vehicles purchased.

Furthermore, a hybrid vehicle incentive can also lead to a significant increase in Hybrid vehicles further helping reduce emissions in the sector. Improving air quality is also a co-benefit and a high priority for Kenya and any discussion of policy options to improve emissions and air quality must consider the optimal role that taxes plays in environmental fiscal reform.

\section{Conclusions}

This study highlights the lack of an effective automobile emission-related tax policy in Kenya. It contributes to the existing literature by establishing a justification for a policy shift that results in a win-win situation with all the major stakeholders affected. These include the government, which can achieve its NDC target by reducing emissions in the transport sector without risking its revenue. Winners also include vehicle importers and owners who are not forced but coerced into purchasing newer and hybrid vehicles via incentives. Finally, the social cost of emissions to the society as a whole is reduced, further reducing the negative externality of the current situation in Kenya.

Strict enforcement of environmental legislation should be a priority in Kenya. The actual emissions reduction will however clearly depend on factors under the vehicle owner's control and in turn, affects the actual amount of emissions emitted per kilometer relative to the Business-as-Usual scenario of the current tax system. We show that the economic and environmental importance of this often-omitted margin needs to be studied further and a simulation of the impact be researched further since existing research of emissions tax implications on consumer behavior is limited in Kenya.

We have shown that fiscal policies such as direct and differentiated carbon taxes need to be used as control mechanisms for countries such as Kenya to influence car choice. On the contrary, implementing similar yet indirect measures such as incorporating a carbon price element in the cost of fuel might prove more difficult to incentivize a behavioral change in purchasing habits. Furthermore, to the extent that car choice is related to taxes imposed on ownership and use, a higher differentiated tax on older vehicles gives people incentives and affordability to own newer vehicles, which carries several complementary benefits mentioned earlier. In addition, this will lead to lower dependence on imported fuels, strengthening the Kenyan economy, as policies dealing with automobile externalities currently in place are ineffective.

However, the study does have some limitations that must be taken into consideration. For future research, the associated air pollutants need to be evaluated to determine the overall impact the current vehicles on Kenyan roads. Emissions data for vehicles are aggregates and not exact figures due to a lack of available 
data. Data was also limited to Light-Duty Vehicles. This could be a focus for future studies to capture the full national vehicle inventory.

\section{Conflicts of Interest}

The authors declare no conflicts of interest regarding the publication of this paper.

\section{References}

[1] Waris, A., Kohonen, M., Mosioma, A. and Ranguma, J. (2009) Taxation and State Building in Kenya: Enhancing Revenue Capacity to Advance Human Welfare. Tax Justice Network Africa/Tax Justice Network International Secretariat, 28.

[2] Kenya National Bureau of Statistics (2015) Kenya Facts and Figures, 2015. KNBS, Nairobi. https://www.knbs.or.ke/download/kenya-facts-2015

[3] Aligula, E.M., Abiero-Gariy, Z., Mutua, J., Owegi, F., Osengo, C. and Olela, R. (2005) Urban Public Transport Patterns in Kenya: A Case Study of Nairobi City. Special Report No. 7. Kenya Institute for Public Policy Research and Analysis, Nairobi, Kenya.

[4] Kinney, P.L., Gichuru, M.G., Volavka-Close, N., Ngo, N., Ndiba, P.K., Law, A., Sclar, E., et al. (2011) Traffic Impacts on PM2.5 Air Quality in Nairobi, Kenya. Environmental Science \& Policy, 14, 369-378.

[5] Louviere, J.J., Hensher, D.A., Swait, J.D. and Adamowicz, W. (2000) Stated Choice Methods. Cambridge University Press, Cambridge.

https://doi.org/10.1017/CBO9780511753831

[6] Horne, M., Jaccard, M. and Tiedemann, K. (2005) Improving Behavioral Realism in Hybrid Energy-Economy Models Using Discrete Choice Studies of Personal Transportation Decisions. Energy Economics, 27, 59-77.

[7] Michalek, J.J., Papalambros, P.Y. and Skerlos, S.J. (2004) A Study of Fuel Efficiency and Emission Policy Impact on Optimal Vehicle Design Decisions. Journal of Mechanical Design, 126, 1062-1070. https://doi.org/10.1115/1.1804195

[8] Harrington, W. and McConnell, V. (2003) Motor Vehicles and the Environment. In: Folmer, H. and Tietenberg, T., Eds., The International Yearbook of Environmental and Resource Economics 2003/2004, Edward Elgar Publishing, Cheltenham. https://doi.org/10.4337/9781781950173.00013

[9] Ogur, E. and Kariuki, S. (2014) Effect of Car Emissions on Human Health and the Environment. International Journal of Applied Engineering Research, 9, 11121-11128.

[10] Faiz, A., Weaver, C.S. and Walsh, M.P. (1996) Air Pollution from Motor Vehicles: Standards and Technologies for Controlling Emissions. World Bank, Washington DC. https://doi.org/10.1596/0-8213-3444-1

[11] Giblin, S. and McNabola, A. (2009) Modelling the Impacts of a Carbon Emission-Differentiated Vehicle Tax System on $\mathrm{CO}_{2}$ Emissions Intensity from New Vehicle Purchases in Ireland. Energy Policy, 37, 1404-1411.

[12] Kenduiwo, J.K. (2016) Development of a Fuel Economy Labeling and Fee Bate Programme for Motor Vehicles in Kenya.

[13] Kuwano, M., Zhang, J. and Fujiwara, A. (2005) Analysis of Ownership Behavior of Low-Emission Passenger Cars in Local Japanese Cities. Proceedings of the Eastern Asia Society for Transportation Studies, 5, 1379-1393.

[14] Romm, J. (2006) The Car and Fuel of the Future. Energy Policy, 34, 2609-2614. 
[15] ERC (2015) Report on Global Fuel Economy Initiative Study in Kenya. Energy Regulatory Commission, Kenya.

[16] Kenya National Bureau of Statistics (2013) Kenya Facts and Figures, 2013. KNBS, Nairobi. https://www.knbs.or.ke/download/kenya-facts-2013/

[17] Kenya National Bureau of Statistics (2016) Economic Survey, 2016. KNBS, Nairobi. https://www.knbs.or.ke/download/economic-survey-2016/

[18] Vehicle Certification Agency Website (2017). http://www.dft.gov.uk/vca/fcb/new-car-fuel-consump.asp

[19] Forest, A. and Sheffrin, S.M. (2002) Complexity and Compliance: An Empirical Investigation. National Tax Journal, 55, 75-88. https://doi.org/10.17310/ntj.2002.1.05

[20] Ciccone, A. (2018) Environmental Effects of a Vehicle Tax Reform: Empirical Evidence from Norway. Transport Policy, 69, 141-157.

\section{Glossary}

$\begin{array}{ll}\mathrm{BAU} & \text { Business as Usual } \\ \mathrm{CO}_{2} & \text { Carbon Dioxide } \\ \mathrm{CC} & \text { Cubic Centimeters (engine size) } \\ \mathrm{CRSP} & \text { Current Retail Selling Price } \\ \mathrm{FDI} & \text { Foreign Direct Investment } \\ \mathrm{GFEI} & \text { Global Fuel Economy Initiative } \\ \mathrm{GCO}_{2} / \mathrm{KM} & \text { Grams of Carbon Dioxide per Kilometre } \\ \mathrm{NDC} & \text { Intended Nationally Determined Contribution } \\ \mathrm{KES} & \text { Kenya Shillings } \\ \mathrm{UN} & \text { United Nations } \\ \mathrm{INTP} & \text { Integrated National Transport Policy } \\ \mathrm{RD} & \text { Reverse Depreciation } \\ \mathrm{HVI} & \text { Hybrid Vehicle Incentive } \\ \mathrm{RDL} & \text { Railway Development Levy } \\ \mathrm{CV} & \text { Customs Value }\end{array}$

